\title{
PERLINDUNGAN HAK CIPTA ATAS EKSPRESI BUDAYA TRADISIONAL PADA KERAJINAN TANGAN DI PROVINSI KEPULAUAN BANGKA BELITUNG
}

Oleh:

\author{
Siti Nurhaini, S.H.
}

\begin{abstract}
This study describes how the copyright protection of traditional cultural expressions on crafts in the province of Bangka Belitung. The study also aimend to determine the role of government on copyright protection of traditional cultural expressions on crafts in the the province of Bangka Belitung. Legal protection of the traditional cultural expressions on the crafts they attempt registration and record-keeping by the government, but there are some traditional cultures are registered and certified by the Ministry of Education and Culture called intangible cultural heritage. The role of government in the protection of copyright in traditional cultural expression in the crafts in this stage is to provide guidance, record keeping and registration by the government. With the government registering traditional cultures in the Pacific Island through the Ministry of Education and Culture annually through several stages of selection by the Ministry Center.
\end{abstract}

Keywords : Legal Protection, Intellectual Property Rights, Traditional Cultural Expressions, Crafts

\section{A. PENDAHULUAN}

Indonesia sebagai negara kepulauan memiliki keanekaragaman seni dan budaya yang sangat kaya. Hal itu sejalan dengan keanekaragaman etnik, suku bangsa, dan agama yang secara keseluruhan merupakan potensi nasional yang perlu dilindungi. Kekayaan seni dan budaya merupakan salah satu sumber dari karya intelektual yang dapat dan perlu dilindungi oleh Undangundang. Kekayaan itu tidak sematamata seni dan budaya itu sendiri, tetapi dapat dimanfaatkan untuk meningkatkan kemampuan dibidang perdagangan dan industri yang melibatkan para penciptanya. Dengan demikian, kekayaan seni dan budaya yang dilindungi itu dapat meningkatkan kesejahteraan, tidak hanya bagi para penciptanya saja, tetapi juga bagi bangsa dan negara. ${ }^{1}$

Perlindungan hak cipta adalah sebagai salah satu tujuan dari diterbitkan seluruh peraturan hukum tentang hak cipta, termasuk konvensi internasional. Oleh karenanya adalah wajar perlindungan yang diberikan terhadap pengolahan dari ciptaan asli

\footnotetext{
*Alumni Fakultas Hukum Universitas Bangka Belitung.

${ }^{1}$ Adrian Sutedi, Hak Atas Kekayaan Intelektual, Sinar Grafika, Jakarta, 2009, hlm. 114.
} 
kepada si pengelola, dengan memperhatikan hak si pencipta asli. ${ }^{2}$

Secara tradisional, hak cipta telah diterapkan kedalam buku-buku, tetapi sekarang hak cipta telah meluas dan mencakup perlindungan atas karya sastra, drama, karya musik dan artistik, termasuk rekaman suara, penyiaran suara film dan televisi dan program komputer. ${ }^{3}$

Sebagai karya bernilai seni, ragam ekspresi budaya seringkali digunakan sebagai sumber inspirasi karya-karya era kini. Lebih dari itu, seringkali digunakan sebagian maupun seluruhnya sebagai elemen bagi karya cipta yang baru. Eksploitasi secara slavish juga lazim terjadi, baik dalam kemasan audio visual, siaran, maupun sebagai bagian dari karya sinematografi. Penempelan juga berlangsung pada karya-karya bersama dan keranjinan tangan ciptaan zaman sekarang. ${ }^{4}$

Bertahun-tahun masyarakat lokal menyaksikan reproduksi yang tidak sah atas ekspersi kebudayaan, seperti karya seni, kerajinan tangan, tari-

${ }^{2}$ OK. Saidin, Aspek Hukum Hak Kekayaan Intelektual, PT. Raja Grafindo Persada, Jakarta, 2007, hlm. 80.

${ }^{3}$ Tim Lindsey, dkk., Hak Kekayaan Intelektual Suatu Pengantar, PT. Alumni, Bandung, 2006, hlm. 6.

${ }^{4}$ Henry Soelistyo, Hak Kekayaan Intelektual Konsepsi Opini dan Aktualisasi, Penaku, Jakarta, hlm. 25. tarian, musik dan drama tradisional. Para pembajak itu tidak meminta izin dan bahkan tidak menyebutkan sumber atau asal-usul ekspresi budaya tersebut. $^{5}$

Sehubungan hal tersebut, perlunya perlindungan terhadap hak cipta pada ekspresi budaya tradisional dilatarbelakangi alasan munculnya kesadaran negara-negara berkembang untuk melindungi kekayaan intelektualnya tersebut, termasuk kepunahannya, berdasarkan hasil FFMs dan penggunaan yang menyimpang oleh negara-negara Barat dengan mengambil dan menggunakan pengetahuan tersebut untuk kepentingan dirinya sendiri melalui klaim HKI. ${ }^{6}$

Pemerintah dapat mencegah adanya monopoli atau komersialisasi serta tindakan yang merusak atau pemanfaatan komersial tanpa seizin negara Republik Indonesia sebagai Pemegang Hak Cipta. Ketentuan ini dimaksudkan untuk menghindari

\footnotetext{
${ }^{5}$ Agus Sardjono, Hak Kekayaan Intelektual dan Pengetahuan Tradisional, PT Alumni, Bandung, 2006, Hlm.87.

${ }^{6}$ Badan Penelitian dan Pengembangan HAM Kementerian Hukum dan HAM RI, Perlindungan Kekayaan Intelektual Atas Pengetahuan Tradisional dan Ekspresi Budaya Tradisional Masyarakat Adat, PT Alumni, Bandung, 2013, hlm. 33.
} 
tindakan pihak asing yang dapat merusak nilai kebudayaan tersebut. ${ }^{7}$

Sebagai pranata, Undang-Undang Hak Cipta dengan tegas telah menjanjikan jaminan perlindungan bagi pencipta dan karya-karya yang dihasilkannya. Itu dilakukan dengan tujuan dan sasaran strategis guna mewujudkan iklim yang kondusif bagi kegairahan masyarakat untuk mencipta. Perlindungan hak cipta pada dasarnya juga diharapkan dapat menjadi stimulan kreativitas sosial dan menunjang pertumbuhan ekonomi nasional. $^{8}$

Namun kenyataannya, ketentuan dalam aturan tersebut masih sulit untuk diimplementasikan. Salah satu alasannya, bahwa pasal ini memerlukan Peraturan Pelaksanaan yang sampai saat ini belum diterbitkan. Karena dalam Pasal ini sudah jelas, bahwa Negaralah sebagai pemegang hak cipta atas Pasal 38 tersebut, jika harus mengingat kepada masyarakat tidak dapat diharapkan untuk secara aktif mengupayakan sendiri perlindungan yang dimaksud ditambah lagi dalam Pasal tersebut bahwa penciptaannya tidak diketahui.

Dalam hal tersebut, harus adanya tindakan dari pemerintah dalam

${ }^{7}$ Tim Lindsey, dkk., Op. Cit., hlm. 112.

${ }^{8}$ Henry Soelistyo, Op. Cit., hlm. 157-158. menjalankan tugas-tugas yang sesuai dengan aturan yang telah ada dan masyarakat setempat khususnya pengrajin daerah. Dengan adanya aturan yang telah berlaku, harusnya lebih ada tindakan khusus dari pemerintah untuk perlindungan hak cipta atas ekspresi budaya tradisional pada kerajinan tangan supaya kejadian-kejadian yang telah banyak terjadi di Indonesia tidak terulang khususnya untuk kerajinan tangan di Bangka Belitung. Dengan banyaknya budaya tradisional di Bangka Belitung, Pemerintah yang sesuai tugasnya melindungi dan memberikan jaminan terhadap budaya tradisional tersebut untuk lebih fokus menjalankan tugasnya dengan selalu memberikan arahan kepada masyarakat dalam hal Pemerintah melindungi hak-hak dari budaya tradisional tersebut.

Berdasarkan uraian tersebut di atas, maka dapat dirumuskan pokok permasalahan, sebagai berikut:

1. Bagaimanakah perlindungan hak cipta atas ekspresi budaya tradisional pada kerajinan tangan di Provinsi Kepulauan Bangka Belitung?

2. Bagaimanakah peran pemerintah dalam perlindungan hak cipta atas ekspresi budaya tradisional pada 
kerajinan tangan di Provinsi

Kepulauan Bangka Belitung?

\section{B. PEMBAHASAN}

1. Perlindungan Hak Cipta Atas Ekspresi Budaya Tradisional pada Kerajinan Tangan di Provinsi Kepulauan Bangka Belitung

Perlindungan hak cipta atas kerajinan tangan merupakan suatu kerajinan tangan yang mempunyai ciri khas atau pembeda dari kerajinan tangan yang lainnnya. Untuk kerajinan tangan dilindungi di dalam ekspresi budaya tradisional ini adalah kerajinan yang berbentuk seni rupa terapan berbentuk 3 (tiga) dimensi yang berupa anyaman dengan pembuatan melakukan secara tradisional. Pembedaan hasil karya cipta yang tidak hanya semata-mata dengan teknik pembuatan karya cipta itu sendiri melainkan pembedaan bahan atau alat yang digunakan dalam pembuatan karya cipta itu sendiri.

Perlindungan hak cipta atas ekspresi budaya tradisional di Indonesia harus dilaksanakan sesuai dengan Pasal 38 ayat (1) dan ayat (2) Undang-Undang Nomor 28 Tahun 2014 tentang Hak Cipta. Berdasarkan Undang-Undang Hak Cipta perlindungan atas ekspresi budaya tradisional sudah mendapatkan perlindungan meskipun hak cipta itu sendiri belum didaftarkan.

Perlindungan hak cipta atas ekspresi budaya tradisional pada kerajinan tangan sudah mendapatkan perlindungan sejak benda yang menjadi objek hak cipta telah berbentuk nyata. Untuk perlindungan hak cipta tidak diharuskan melakukan pendaftaran, namun pendaftaran dilakukan untuk mendapatkan alat bukti berupa surat pendaftaran jika suatu saat terjadi permasalahan di bidang Hak Cipta. Objek hak cipta bisa dijadikan alat bukti dengan berupa surat pendaftaraan yang menjadi hak kebendaan bagi pemegang hak cipta.

Perlindungan hak cipta dilakukan dengan pendaftaran di Kementerian Hukum dan HAM khususnya Direktorat Jenderal Hak Kekayaan Intelektual dengan berdasarkan ketentuan perundang-undangan. Perlindungan hak cipta di Direktorat Jenderal Hak Kekayaan Intelektual dengan mendaftarkan ekspresi budaya tradisional dan dicatat dalam daftar umum ciptaan. Pendaftaran atas ekspresi budaya tradisional dilakukan untuk mendata, menginventarisir serta mengawasi ekspresi budaya tradisional yang 
belum terdaftar agar tidak terjadi tindakan yang merugikan penciptanya. $^{9}$

Selain perlindungan hak cipta pada ekspresi budaya tradisional yang didaftarkan di Kementerian Hukum dan HAM khususnya Direktorat Jenderal Hak Kekayaan Intelektual, perlindungan hak cipta atas ekspresi budaya tradisional juga bisa didaftarkan di Kementerian Pendidikan dan Kebudayaan Pusat. Pendaftaran ini dilakukan oleh Pemerintah Provinsi yang bekerja sama dengan Pemerintahan Daerah yang untuk mengajukan ke Kementerian Pendidikan dan Kebudayaan dengan beberapa tahap. Permohonan pendaftaran di Kementerian Pendidikan dan Kebudayaan Pusat dikenal dengan pendaftaran atas warisan budaya dari tiap-tiap provinsi. Warisan budaya itu sendiri dapat didaftarkan dengan daya pembeda atas warisan budaya dari daerah lainnya. Adapun tahaptahap pengajuan untuk permohonan pendaftaran atas ekspresi budaya tradisional, sebagai berikut:

1) Tahap pengkajian warisan budaya itu sendiri;

${ }^{9}$ Wawancara dengan I.C. Siregar, Kepala Bidang Pelayanan Hukum, Kementerian Hukum dan HAM RI Kantor Wilayah Kepulauan Bangka Belitung, Hari Kamis Tanggal 19 Mei 2016.
2) Tahap pengawasan;

3) Tahap Uji Kebenaran. ${ }^{10}$

Beberapa tahap yang dilakukan oleh Kementerian Pendidikan dan Kebudayaan Pusat bertujuan untuk melindungi warisan budaya yang ada di Indonesia. Perlindungan hak cipta atas ekspresi budaya tradisional khususnya kerajinan tangan, mendapatkan berupa sertifikat yang dikeluarkan oleh Kementerian Pendidikan dan Kebudayaan Pusat yang telah diakui oleh Organisasi Internasional di bidang Kebudayaan, yakni UNESCO. Namun, setiap tahunnya Kementerian Pendidikan dan Kebudayaan Pusat hanya meminta 5 (lima) warisan budaya yang mendapatkan sertifikat dengan tahap-tahap sesuai penjelasan yang diatas. Dengan adanya sertifikat yang dikeluarkan oleh Kementerian Pendidikan dan Kebudayaan, maka pihak asing maupun pihak lokal tidak bisa mengklaim warisan budaya yang telah mempunyai pengakuan dari UNESCO. ${ }^{11}$

Untuk perlindungan hak cipta atas ekspresi budaya tradisional, khususnya pada kerajinan tangan di

\footnotetext{
${ }^{10}$ Wawancara dengan Engkus, Sekretaris Dinas Provinsi Kepulauan Bangka Belitung, Hari Rabu Tanggal 24 Februari 2016.

${ }^{11}$ Wawancara dengan Engkus, Sekretaris Dinas Provinsi Kepulauan Bangka Belitung, Hari Rabu Tanggal 24 Februari 2016.
} 
Provinsi Kepulauan Bangka Belitung berpedoman dengan undang-undang hak cipta dan berpedoman pada sertifikat yang mendapatkan pengakuan langsung dari Organisasi Internasional di bidang Kebudayaan.

2. Peran Pemerintah dalam Perlindungan Hak Cipta Atas Ekspresi Budaya Tradisional Pada Kerajinan Tangan di Provinsi Kepulauan Bangka Belitung

Berdasarkan Pasal 38 ayat (1) jelas bahwa hak cipta ekspresi budaya tradisional di pegang oleh Negara. Peran negara (dalam hal ini pemerintahan) menjadi penting, karena kerajinan tangan yang diwariskan turun temurun mempunyai nilai ekonomis yang sangat melekat terhadap hak pengrajin di perdagangan dan bisa menjadi kebanggan untuk daerah itu sendiri terhadap budaya-budaya tradisional yang ada di daerah masing-masing. Dalam hal perdagangan, tidak hanya melibatkan subjek hukum, namun juga melibatkan pemerintah sebagai subjeknya. Negara yang menjalankan fungsi pengatur (regulator) juga harus memainkan peran pentingnya sebagai penyedia (provider). Negara dalam hal ini pemerintah, harus menjadi penyeimbang (balancer) bagi berbagai kepentingan masyarakat.

Peran pemerintah sampai saat ini masih upaya sosialisasi, pencatatan, pengawasan, pelestarian, pembinaan serta menyelenggarakan pendaftaran di daerah-daerah tertentu, antara lain:

1) Sosialisasi dilakukan oleh pihak Pemerintah Daerah maupun Pemerintah Provinsi dengan tujuan agar pemahaman maupun keberadaan ekspresi budaya tradisional harus dilindungi secara hukumnya kepada masyarakat lokal dan kepengrajin-pengrajin khususnya kerajinan tangan. Sosialisasi ini setidaknya bisa membantu pemikiran dari masyarkat lokal itu terhadap pentingnya perlindungan atas ekspresi budaya tradisional yang dibuat oleh pengrajin ini dengan sama-sama melakukan upaya perlindungan terhadap apa yang pengrajin lakukan atas warisan budaya itu sendiri agar pengrajin bukan hanya sekedar mengetahui cara membuat suatu hasil karya intelektual dibidang kerajinan tangan melainkan untuk melindungi dari hasil kerajinan pengrajin sendiri baik dari pihak lokal maupun pihak asing. 
2) Pencatatan dilakukan sebagai upaya awal yang diberikan oleh pihak Pemerintah untuk mendapatkan data-data secara benar atas kerajinan tangan yang ada di Bangka Belitung. Pencatatan dilakukan oleh Pemerintah Daerah maupun Pemerintah Provinsi untuk langsung ke pengrajin-pengrajin untuk mendata kerajinan tangan apa saja yang menjadi warisan budaya yang termasuk dalam ekspresi budaya tradisional yang selanjutnya akan didaftarkan di Kementerian Pendidikan dan Kebudayaan Pusat.

3) Pengawasan dilakukan terhadap pengrajin atas hasil karya ciptaannya dengan memastikan bahwa kerajinan tangan yang dihasilkan masih mempunyai warisan turun temurun yang bisa menjadi nilai ekonomi dalam perdagangan. Dalam pengawasan ini juga bertujuan agar membuka jaringan kerja kepada pengrajin untuk memenuhi hak ekonomi dari pengrajin.

4) Pelestarian dilakukan oleh Pemerintah Daerah dengan memberikan alat, bahan yang digunakan untuk membuat kerajinan tangan kepada pengrajin-pengrajin sesuai dengan kebutuhan dan permintaan pengrajin. Untuk peralatan yang di berikan oleh Pemerintah tidak langsung bisa diberikan cumacuma oleh Pemerintah karena harus melalui proses administrasi dari pihak Pemerintah itu sendiri.

5) Pembinaan dilaksanakan oleh Pemerintah Daerah maupun Pemerintah Provinsi dengan mendatangkan pihak luar (orang yang mempunyai keahlian dalam bidang kerajinan tangan) untuk melakukan pembinaan ketiap-tiap pengrajin untuk belajar cara membuat kerajinan tangan yang modern sesuai perkembangan zaman, namun tidak menghilangkan budaya dari wilayah itu sendiri. Hal ini bertujuan agar pengrajin lebih menuangkan ide-ide dalam melestarikan warisan budaya lebih bersifat modern dengan memperbanyak koleksi kerajinan tangan yang akan di perdagangkan.

6) Penyelenggaraan Pendaftaran untuk hak cipta yang tidak diketahui penciptanya didaftarkan oleh Pemerintah Provinsi bekerja sama dengan Pemerintah Daerah masing-masing yang mempunyai 


kerajinan tangan tradisional,
pendaftaran ini di daftarkan baik
di Kementerian Hukum dan HAM
khususnya Direktorat Jenderal
Hak Kekayaan Intelektual dengan
dicatatnya kerajinan tangan
kedalalm daftar umum ciptaan
yang nantinya akan mendapatkan
surat pendaftaran yang
dikeluarkan oleh Kementerian
Hukum dan HAM dan di
Kementerian Pendidikan dan
Kebudayaan Pusat dengan
mendapatkan penghargaan berupa
sertifikat warisan budaya
takbenda Indonesia yang diakui
Organisasi Internasional
UNESCO.

Peran Pemerintah diatas bertujuan untuk melindungi warisan budaya yang tidak diketahui penciptanya dari pihak lokal maupun asing agar tidak terjadinya permasalahan pengklaiman warisan budaya yang ada di Bangka Belitung. Hal ini untuk membantu hak-hak pengrajin dalam memenuhi hak ekonomi dalam melestarikan warisan budaya yang menjadi kebanggaan di Daerah masing-masing.

Pemerintah Daerah dalam perlindungan kerajinan tangan selain melakukan upaya pertama melakukan sosialisasi, pencatatan, pengawasan, pembinaan, pelestarian serta pendaftaran. Pemerintah Daerah juga ingin melindungi hak cipta atas ekspresi budaya tradisional dengan membentuk Rancangan Peraturan Daerah atau pun Peraturan Bupati mengenai warisan budaya yang ada ditiap-tiap Daerah. Hal ini dikarenakan banyaknya warisan budaya yang ada di Bangka Belitung yang bisa menjadikan kebanggan untuk Daerah maupun Provinsi di tingkat Nasional maupun Internasional. $^{12}$

Dengan demikian, peran pemerintah dalam melindungi hak cipta atas ekspresi budaya tradisional sudah dilakukan dengan beberapa upaya, seperti melakukan sosialisasi, pencatatan, pengawasan, pelestarian, pembinaan serta menyelenggarakan pendaftaran yang dilakukan oleh Pemerintah Provinsi maupun Pemerintah Daerah. Tidak hanya itu peran pemerintah untuk melindungi hak cipta atas ekspresi budaya tradisional pada kerajinan tangan sudah dalam Rancangan pembentukan Peraturan Daerah ataupun Peraturan Bupati mengenai warisan budaya yang ada ditiap-tiap

\footnotetext{
${ }^{12}$ Wawancara dengan Sukandi, Kepala Bidang Kebudayaan Dinas Perhubungan, Pariwisata, Kebudayaan dan Informatika, Hari Senin Tanggal 29 Februari 2016.
} 
wilayah Bangka Belitung. Peran pemerintah ini bertujuan sematamata untuk melindungi hasil karya ciptaan pengrajin dari monopoli atau komersialisasi yang merusak kearifan lokal dari hasil karya ciptaan atas ekspresi budaya tersebut.

\section{PENUTUP}

1. Perlindungan hukum terhadap ekspresi budaya tradisional pada kerajinan tangan dapat dilakukan dengan mengajukan permohonan pendaftaran hak cipta di Kementerian Hukum dan HAM, khususnya Direktorat Jenderal Hak Kekayaan Intelektual untuk dicatat dalam daftar umum ciptaan dan permohonan pendaftaran di Kementerian Pendidikan dan Kebudayaan Pusat yang dilakukan oleh Pemerintah Provinsi dengan Pemerintah Daerah untuk mendapatkan penghargaan berupa sertifikat terhadap pengakuan warisan budaya takbenda Indonesia yang telah diakui oleh Organisasi Internasional UNESCO. Perlindungan ini bertujuan untuk melindungi hakhak dari pengrajin atas hasil karya ciptaannya dari monopoli atau komersialisasi yang merugikan pencipta atau pengrajinn dan merusak nilai kearifan lokal dari ekspresi budaya tersebut.

2. Peran Pemerintah terhadap perlindungan Hak Cipta atas ekspresi budaya tradisional sudah dilakukan oleh Pemerintah Provinsi maupun Pemerintah Daerah dengan melakukan sosialisasi, pencatatan, pengawasan, pelestarian, pembinaan serta menyelenggarakan pendaftaran terhadap warisan budaya tradisional yang ada di Bangka Belitung. Selain itu peran Pemerintah juga untuk melindungi ekspresi budaya tradisional melakukan pembentukan Rancangan Peraturan Daerah ataupun Peraturan Bupati untuk tiap-tiap Daerah yang mempunyai warisan budaya tradisional.

\section{DAFTAR PUSTAKA}

Adrian Sutedi, 2009, Hak Atas Kekayaan Intelektual, Jakarta: Sinar Grafika.

Agus Sardjono, 2006, Hak Kekayaan Intelektual dan Pengetahuan Tradisional, Bandung: PT Alumni.

Badan Penelitian dan Pengembangan HAM Kementerian Hukum dan HAM RI, 2013, Perlindungan 
Kekayaan Intelektual Atas Pengetahuan Tradisional dan Ekspresi Budaya Tradisional Masyarakat Adat, , Bandung: PT Alumni.

Henry Soelistyo, 2014, Hak Kekayaan Intelektual Konsepsi Opini dan Aktualisasi, , Jakarta: Penaku

OK. Saidin, 2007, Aspek Hukum Hak Kekayaan Intelektual, Jakarta: PT Raja Grafindo Persada.

Tim Lindsey dkk., 2006, Hak Kekayaan Intelektual Suatu Pengantar, Bandung: PT. Alumni. 